\author{
ALEKSANDRA GŁÓWCZEWSKA \\ ORCID: 0000-0002-3898-8822 \\ Uniwersytet Mikołaja Kopernika w Toruniu \\ DOMINIKA ZAWACKA-KLONOWSKA \\ ORCID: 0000-0003-3434-0129 \\ Uniwersytet Mikołaja Kopernika w Toruniu

\section{CHARAKTER PRAWNY ZAŚWIADCZEŃ WYDAWANYCH PRZEZ PODMIOTY PRYWATNE ORAZ PROCEDURA ICH WYDAWANIA}

\begin{abstract}
Abstrakt: Niniejsze opracowanie zawiera analizę poglądów doktryny i orzecznictwa sądów administracyjnych i powszechnych w celu rozstrzygnięcia zagadnienia wydawania zaświadczeń przez podmioty prywatne. Autorki podjęły próbę klasyfikacji zaświadczenia prywatnego oraz trybu jego wydawania. Celem opracowania było wskazanie na obowiązek wydania zaświadczenia na żądanie uprawnionego, ciążący na podmiotach prywatnych oraz na kwestię ochrony prawnej przysługującej uprawnionemu.
\end{abstract}

Słowa kluczowe: zaświadczenie, podmiot prywatny, tryb wydawania zaświadczeń przez podmioty prywatne, postępowanie w sprawach wydawania zaświadczeń

\title{
WPROWADZENIE
}

Ustawa z dnia 14 czerwca 1960 roku — Kodeks postępowania administracyjnego $^{1}$ (dalej: k.p.a.) normuje tryb wydawania zaświadczeń przez organy administracji publicznej (dalej: o.a.p.) w rozumieniu art. $5 \S 1$ pkt 3 k.p.a. Pojęcie zaświadczenia, regulowane w k.p.a., i jego charakter prawny nie budzą większych wątpliwości w doktrynie i orzecznictwie sądowoadministracyjnym ${ }^{2}$. Tego samego nie można powiedzieć o zaświadczeniach wydawanych przez podmioty niemiesz-

1 Tekst jedn. Dz.U. z 2020 r. poz. 256 ze zm.

2 Z.R. Kmiecik, Charakter prawny zaświadczenia a możliwość ustalania $i$ weryfikacji jego treści, „Państwo i Prawo” 2004, nr 10, s. 58; por. M. Jaśkowska, [w:] Kodeks postępowania administracyjnego. Komentarz aktualizowany, red. M. Wilbrandt-Gotowicz, A. Wróbel, M. Jaśkowska, Gdańsk 2020, LEX; wyrok WSA w Gdańsku z dnia 10 listopada 2020 r., II SA/Gd 524/20, CBOSA; wyrok WSA w Warszawie z dnia 6 listopada 2020 r., II SA/Wa 2632/19, CBOSA. 
czące się w katalogu o.a.p. Wśród nich należy wymienić organy ustawodawcze, organy kontroli zewnętrznej, sądy a także podmioty prywatne. Ta ostatnia grupa podmiotów pozostaje w zainteresowaniu autorek opracowania.

Celem niniejszego artykułu jest próba określenia charakteru prawnego zaświadczenia wydawanego przez podmioty prywatne, a także ustalenia, w jakim trybie zaświadczenia takie zostają wydane. Autorki poszukują odpowiedzi na pytanie, czy istnieją mechanizmy prawne umożliwiające osobom ubiegającym się o wydanie przedmiotowego zaświadczenia w sytuacjach bezczynności podmiotów prywatnych.

\section{ZAŚWIADCZENIA WYDAWANE PRZEZ ORGANY ADMINISTRACJI PUBLICZNEJ}

\subsection{ZAŚWIADCZENIE I JEGO CHARAKTER PRAWNY}

Zaświadczenie jest jedną z form działania administracji publicznej ${ }^{3}$. Przepisy działu VII, regulujące materię związaną z wydawaniem zaświadczeń przez organy administracji publicznej, zostały wprowadzone do k.p.a. na mocy nieobowiązującej już ustawy z dnia 31 stycznia 1980 roku o Naczelnym Sądzie Administracyjnym oraz o zmianie ustawy - Kodeks postępowania administracyjnego ${ }^{4}$.

K.p.a. nie wprowadza legalnej definicji tego pojęcia, co stworzyło potrzebę jego zdefiniowania w doktrynie. Podejmowało się tego wielu przedstawicieli nauki, specjalizujących się w sprawach postępowania administracyjnego. J. Lang w swoim artykule wskazywał, że użyte przez ustawodawcę określenie „zaświadczenie” ma węższe znaczenie niż „zaświadczenie” rozumiane potocznie. Jego zdaniem zaświadczenie jest typem czynności podejmowanych przez organy administracji publicznej w rozumieniu k.p.a. „Jeżeli kodeks mówi o zaświadczeniu jako oddzielnej czynności organu administracyjnego [...] to trzeba uznać, że ustawodawca przez zaświadczenie rozumiał co innego niż decyzja administracyjna, postanowienie, wezwanie, zeznanie świadka, opinie biegłego itp." ${ }^{5}$. W podobnym tonie wypowiedział się NSA w postanowieniu z dnia 10 marca 1986 roku: ,zaświadczenia nie stanowią decyzji w rozumieniu art. 104 k.p.a., lecz wydawane są w trybie przepisów zawartych w art. 217-220 k.p.a."6.

3 K. Klonowski, art. 217, [w:] Kodeks postepowania administracyjnego. Komentarz, red. H. Knysiak-Sudyka, Warszawa 2019, LEX.

${ }^{4}$ Dz.U. z 1980 r. Nr 4, poz. 8.

5 J. Lang, Zaświadczenia w rozumieniu kodeksu postępowania administracyjnego, „Organizacja, Metody, Technika" 1988, nr 2, s. 13-14.

6 Postanowienie NSA z dnia 10 marca 1986 r., II SA 293/86, za: J. Borkowski, [w:] Postepowanie administracyjne i sadowoadministracyjne, red. B. Adamiak, J. Borkowski, Warszawa 2018, s. 759 . 
Według Z.R. Kmiecika, by mówić o zaświadczeniu w rozumieniu przepisów k.p.a., akt ten musi spełniać następujące warunki:

1. pochodzić od o.a.p. - art. $217 \S 1$ ab initio k.p.a.,

2. zostać wydany na żądanie osoby ubiegającej się o zaświadczenie — art. 217 $\S 1$ in fine k.p.a.,

3. mieć na celu urzędowe potwierdzenie określonych faktów lub stanu prawnego - art. $217 \S 2$ pkt 1 k.p.a. lub mieć znaczenie dla adresata przy ustalaniu jego praw lub obowiązków — art. $217 \S 2$ pkt 2 k.p.a. ${ }^{7}$

J. Lang z kolei wymienia pięć przesłanek, których zaistnienie daje możliwość uznania aktu za zaświadczenie w rozumieniu k.p.a.:

1. wydanie aktu muszą przewidywać przepisy prawa, zarówno kompetencyjne, jak i proceduralne,

2. akt ten wydawany jest na żądanie osoby ubiegającej się o zaświadczenie,

3. osoba ubiegająca się powinna uprawdopodobnić swój interes prawny w urzędowym potwierdzeniu faktów,

4. akt ma na celu potwierdzenie określonych faktów lub stanu prawnego,

5. jest wydawany przez o.a.p. oraz inne organy, powołane do stosowania przepisów k.p.a. ${ }^{8}$

Przekonania przedstawicieli doktryny, co do istoty i charakteru prawnego zaświadczenia, nie są jednolite ${ }^{9}$. Z.R. Kmiecik, powołując się na J. Langa, klasyfikuje te poglądy w następujące grupy:

1) zaświadczenie jest rodzajem aktu administracyjnego,

2) zaświadczenie nie jest aktem administracyjnym, lecz inną (odrębną) czynnością prawną administracji,

3) zaświadczenie nie jest czynnością prawną, lecz faktyczną,

4) granica między zaświadczeniem a aktem administracyjnym jest nieostra i zależnie od okoliczności zaświadczenie może być aktem administracyjnym albo nim nie być ${ }^{10}$.

Wspólnym pozostaje określenie, że zaświadczenie potwierdza wyłącznie stan rzeczy ${ }^{11}$, ma ,cechę urzędowej informacji o stanie prawnym lub faktycznym w danym czasie" 12 .

Zagadnienie charakteru prawnego zaświadczenia na gruncie k.p.a. było także przedmiotem rozstrzygnięć sądów administracyjnych. NSA nazywa zaświadczenie „czynnością faktyczną organu”13, wskazując, iż „zaświadczenie jest aktem

7 Z.R. Kmiecik, Instytucja zaświadczenia w prawie administracyjnym, Lublin 2002, s. 19-22.

8 J. Lang, op. cit., s. 14.

9 J. Borkowski, [w:] B. Adamiak, J. Borkowski, Postepowanie administracyjne..., s. 759.

10 Z.R. Kmiecik, Instytucja zaświadczenia ..., s. 27; por. J. Lang, Poglady nauki na funkcje i charakter zaświadczeń, „Organizacja, Metody,Technika” 1988, nr 1, s. 45-46.

11 J. Lang, Instytucja zaświadczenia ..., s. 16.

12 J. Borkowski, [w:] B. Adamiak, J. Borkowski, Postępowanie administracyjne ..., s. 759.

13 Wyrok NSA z dnia 13 października 2005 r., II GSK 133/05, CBOSA. 
wiedzy organu, a nie aktem woli organu i nie ma charakteru prawotwórczego"14. „Zaświadczenie jest pochodną istniejących faktów lub stanu prawnego i wraz ze zmianą tych faktów i stanu prawnego - zaświadczenie staje się nieaktualne i może być wydane nowe, odpowiadające aktualnemu stanowi prawnemu lub aktualnym faktom" 15 .

Istotą zaświadczenia jest to, że jest ono przejawem wiedzy, a nie woli organu administracji publicznej. „Zaświadczenie jest czynnością materialno-techniczną i urzędowym potwierdzeniem określonych faktów lub stanu prawnego. Dlatego nie rozstrzyga o żadnych prawach lub obowiązkach, nie może też tworzyć nowej sytuacji prawnej. Zaświadczenie może jedynie potwierdzać istnienie określonych faktów lub stanu prawnego"16.

Nie ma wątpliwości, że zaświadczenie wydawane przez o.a.p. jest dokumentem urzędowym w myśl art. $76 \S 1$ k.p.a. Wobec tego korzysta $z$ dwóch domniemań prawnych - domniemania prawdziwości, które oznacza, że zaświadczenie pochodzi od organu, który je wystawił oraz domniemania zgodności z prawdą oświadczenia organu, od którego pochodzi. By jednak zaświadczenie mogło z nich skorzystać, musi — zgodnie z art. $76 \S 1$ k.p.a. — być sporządzone w przepisanej formie przez powołane do tego organy w ich zakresie działania, to znaczy zgodnie z ich właściwością rzeczową i miejscową.

\subsection{PODMIOTY UPRAWNIONE DO WYDAWANIA ZAŚWIADCZEŃ W ROZUMIENIU K.P.A.}

Zgodnie z dyspozycją art. $217 \S 1$ ab initio k.p.a., by móc mówić o zaświadczeniu, akt ten musi pochodzić od organu administracji publicznej. Kodeks postępowania administracyjnego w art. $5 \S 2$ pkt 3 wskazuje, co należy rozumieć przez pojęcie o.a.p. W myśl tego przepisu o.a.p. są ministrowie, centralne organy administracji rządowej, wojewodowie, działające w ich lub we własnym imieniu inne terenowe organy administracji rządowej (zespolonej i niezespolonej), organy jednostek samorządu terytorialnego, jak również inne organy państwowe oraz podmioty. Zatem organami właściwymi do prowadzenia przedmiotowego postępowania i wydania zaświadczenia są organy administracji publicznej w ujęciu funkcjonalnym ${ }^{17}$. Przepisy działu VII k.p.a. nie mają zatem zastosowania do organów państwowych niebędących organami administracji (organów władzy ustawodawczej, organów kontroli, sądów), organów samorządów zawodowych i gospodarczych, organów państwowych i samorządowych jednostek organizacyjnych oraz organizacji społecznych, gdy nie przewiduje tego wyraźnie upoważ-

\footnotetext{
14 Wyrok NSA z dnia 12 kwietnia 2018 r., II OSK 2527/17, CBOSA.

15 Wyrok NSA w Warszawie z dnia 28 czerwca 1983 r., I SA 268/83, ONSA 1983/1/47.

16 Wyrok NSA z dnia 1 lipca 2010 r., II OSK 594/10, CBOSA.

17 J. Borkowski, [w:] B. Adamiak, J. Borkowski, Postępowanie administracyjne..., s. 757.
} 
nienie ustawowe bądź porozumienie administracyjne ${ }^{18}$. Tylko zaświadczenie wydane przez organ właściwy rzeczowo i miejscowo jest dokumentem urzędowym w rozumieniu art. 76 k.p.a. ${ }^{19}$ Organem właściwym do wydania zaświadczenia będzie więc organ posiadający rejestr, ewidencję lub inną dokumentację pozwalającą określić okoliczności prawne lub faktyczne, których potwierdzenia domaga się osoba ubiegająca się o wydanie zaświadczenia. Jednakże w k.p.a. nie zostały uregulowane przepisy dotyczące ustalania właściwości organów w sprawach wydawania zaświadczeń. Rzadko też spotkać się można z sytuacją, w której to przepisy szczególne będą wskazywały organ właściwy do wydania zaświadczenia. Pojawia się zatem pytanie, jak określać właściwość miejscową i rzeczową organu? Według Z.R. Kmiecika:

należy uznać, iż — poza przypadkami, gdy określone są organy właściwe do wydawania poszczególnych rodzajów zaświadczeń, a także gdy przepisy mówią o właściwości organu do załatwienia wszelkich spraw danej kategorii (a nie tylko spraw rozstrzyganych w drodze decyzji) - organ właściwy do wydawania zaświadczenia ustala się według przepisów stanowiących o właściwości rzeczowej organów w sprawach załatwianych przez wydawanie decyzji. [...] organem właściwym do wydania zaświadczenia dotyczącego danej kategorii spraw powinien być organ, który w tej kategorii spraw jest właściwy do wydawania decyzji administracyjnych ${ }^{20}$,

przy czym należy pamiętać, że nie zawsze właściwość organu do wydawania zaświadczenia pokrywa się z właściwością tego organu do wydawania decyzji administracyjnej ${ }^{21}$. Właściwość miejscową organów ustala się na podstawie regulacji art. 21 k.p.a.

\subsection{PODMIOTY UPRAWNIONE DO UBIEGANIA SIĘ O ZAŚWIADCZENIE W ROZUMIENIU K.P.A.}

Zgodnie z art. $217 \S 1$ k.p.a. zaświadczenie wydaje się na żądanie osoby ubiegającej się o nie. Postępowanie w sprawach wydawania zaświadczeń jest jednym z rodzajów postępowań pozajurysdykcyjnych, wobec czego określenia „osoba ubiegająca się" nie można utożsamiać z pojęciem strony postępowania administracyjnego, o którym mowa $\mathrm{w}$ art. 28 k.p.a. W doktrynie podkreśla się, że „o zaświadczenie może ubiegać się każdy, niezależnie od obywatelstwa czy statusu prawnego" 22 . W kręgu osób uprawnionych znajdują się osoby fizyczne, osoby prawne oraz państwowe i samorządowe jednostki organizacyjne a także organizacje społeczne nieposiadające osobowości prawnej. Jak podnosi Z. Janowicz, skoro te ostatnie podmioty mogą być stroną w jurysdykcyjnym postępowaniu

18 Por. Z.R. Kmiecik, Instytucja zaświadczenia..., s. 60.

19 R. Orzechowski, [w:] J. Borkowski et al., Kodeks postępowania administracyjnego. Komentarz, Warszawa 1989, s. 368.

20 Z.R. Kmiecik, Instytucja zaświadczenia..., s. 61.

${ }^{21}$ Przykłady takich sytuacji prezentuje Z.R. Kmiecik, ibidem, s. 62-68.

22 K. Klonowski, op. cit. 
administracyjnym, to tym bardziej mogą występować jako podmioty uprawnione do ubiegania się o uzyskanie zaświadczenia ${ }^{23}$. Przeciwny pogląd prezentował J. Lang, którego zdaniem

nie powinno się [...] obejmować tym pojęciem na przykład państwowych jednostek organizacyjnych nieposiadających osobowości prawnej [...], gdyż postępowanie w sprawie zaświadczeń uregulowane w kodeksie jest w dużym stopniu odformalizowane, co może być pożyteczne tam, gdzie wobec administracji występują osoby fizyczne, natomiast nie jest celowe wszędzie tam, gdzie mają miejsce działania wewnątrzadministracyjne ${ }^{24}$.

\subsection{PRZESŁANKI WYDAWANIA ZAŚWIADCZEŃ W ROZUMIENIU K.P.A.}

W myśl art. 217 § 2 k.p.a. zaświadczenie wydaje się, jeżeli:

1. urzędowego potwierdzenia określonych faktów lub stanu prawnego wymaga przepis prawa;

2. osoba ubiega się o zaświadczenie ze względu na swój interes prawny w urzędowym potwierdzeniu określonych faktów lub stanu prawnego.

Oznacza to, że podmiot, który zwraca się do organu o wydanie zaświadczenia, obowiązany jest bądź to wskazać przepis prawa, z którego wynika obowiązek uzyskania urzędowego potwierdzenia określonych faktów lub stanu prawnego ${ }^{25}$, bądź wykazać we wniosku swój interes prawny. Wynika z tego, że „ustawodawca rozróżnia dwa rodzaje zaświadczeń tj.: zaświadczenia wydawane, gdy wymaga tego przepis prawa (art. $217 \S 2$ pkt 1 k.p.a.) oraz zaświadczenia wydawane na żądanie strony mającej interes prawny (art. 217 § 2 pkt 2 k.p.a.)”. W odniesieniu do pierwszej przesłanki o.a.p. ma obowiązek wydania zaświadczenia, o ile stosowne dane znajdują się w jego posiadaniu. Interes prawny osoby ubiegającej się o wydanie zaświadczenia nie podlega w takiej sytuacji badaniu, bowiem jest on z góry ustalony przez przepis prawa. Natomiast gdy podmiot domaga się wydania zaświadczenia, powołując się na swój interes prawny, organ musi przed wydaniem zaświadczenia ustalić, czy osoba ubiegająca się rzeczywiście posiada interes prawny w urzędowym potwierdzeniu określonych faktów lub stanu prawnego. Obowiązek wydania zaświadczenia powstaje wówczas z chwilą stwierdzenia istnienia interesu prawnego. Jeżeli organ stwierdzi, że osoba ubiegająca się takiego interesu nie ma - odmawia wydania zaświadczenia lub zaświadczenia o żądanej treści ${ }^{26}$. Przesłanka występowania interesu prawnego może być przedmiotem

${ }^{23}$ Z. Janowicz, Postępowanie administracyjne i postepowanie przed sądem administracyjnym, Warszawa-Poznań 1987, s. 315-316.

24 J. Lang, Instytucja zaświadczenia..., s. 14.

${ }^{25} \mathrm{Z}$ obowiązkiem urzędowego potwierdzenia określonych faktów lub stanu prawnego w formie zaświadczenia wiąże się obowiązek, a nie uprawnienie podmiotu do występowania przed organ o wydanie przedmiotowego zaświadczenia.

${ }^{26}$ Wyrok NSA z dnia 17 stycznia 2020 r., I OSK 3535/18, CBOSA. NSA niepoprawnie użył sformułowania „strona”. Lepsze byłoby użycie określanie, którym posługuje się k.p.a., mianowicie „osoba ubiegająca się o zaświadczenie”. 
przeprowadzonego przez organ postępowania wyjaśniającego, przy czym organ może przeprowadzić postępowanie wyjaśniające także w celu zbadania okoliczności, które miałyby być potwierdzone zaświadczeniem ${ }^{27}$.

\section{ZAŚWIADCZENIA WYDAWANE PRZEZ PODMIOTY PRYWATNE}

\subsection{CHARAKTER PRAWNY ZAŚWIADCZEŃ WYDAWANYCH PRZEZ PODMIOTY PRYWATNE}

Wydawanie zaświadczeń nie pozostaje wyłączną kompetencją o.a.p. w rozumieniu art. $5 \S 2$ pkt 3 k.p.a. Zaświadczenia mogą być i są wydawane także przez podmioty prywatne. Do tego rodzaju postępowań nie mają zastosowania przepisy k.p.a. Tym samym procedura wydawania oraz same zaświadczenia mają nieco odmienny charakter. Wynika to $\mathrm{z}$ faktu, że w zakresie, w jakim podmioty te będą obowiązane wydawać zaświadczenia, nie będą wykonywać funkcji publicznych.

Zaświadczenie wydane przez podmiot prywatny nie będzie dokumentem urzędowym w rozumieniu k.p.a. Zgodnie z treścią $§ 2$ art. 76 k.p.a., przepis art. 76 $\S 1$ k.p.a. stosuje się odpowiednio do dokumentów urzędowych sporządzanych przez organy jednostek organizacyjnych lub podmioty, w zakresie poruczonych im z mocy prawa lub porozumienia spraw wymienionych w art. 1 pkt 1 i 4 k.p.a. ${ }^{28}$ Podobnie definiowane są dokumenty urzędowe w ustawie $\mathrm{z}$ dnia 17 listopada 1964 roku - Kodeks postępowania cywilnego ${ }^{29}$ (dalej: k.p.c.), w której zgodnie $\mathrm{z}$ art. $244 \S 1$ k.p.c. dokumenty urzędowe są sporządzone w przepisanej formie przez powołane do tego organy władzy publicznej i inne organy państwowe w zakresie ich działania i stanowią dowód tego, co zostało w nich urzędowo zaświadczone. Przepis ten stosuje się odpowiednio do dokumentów urzędowych sporządzonych przez podmioty, inne niż wymienione w art. $244 \S 1$ k.p.c., w zakresie zleconych im przez ustawę zadań z dziedziny administracji publicznej (art. 244 $\S 2$ k.p.c.). Do grupy tych podmiotów nie można zaliczyć podmiotów prywatnych, gdyż te nie wykonują zadań zleconych z dziedziny administracji. Dokumentem urzędowym nie będzie więc zaświadczenie o stanie zdrowia, zaświadczenie o zarobkach czy świadectwo pracy ${ }^{30}$. To ostatnie ma szczególny charakter, na który warto zwrócić uwagę.

27 B. Adamiak, J. Borkowski, Kodeks postępowania administracyjnego. Komentarz, Warszawa 2021, Legalis.

${ }^{28}$ Chodzi tu o postępowanie przed organami administracji publicznej w należących do właściwości tych organów sprawach indywidualnych rozstrzyganych w drodze decyzji administracyjnych albo załatwianych milcząco oraz o postępowanie w sprawach wydawania zaświadczeń.

29 Tekst jedn. Dz.U. z 2020 r. poz. 1575 ze zm.

30 A. Cempura, A. Kasolik, 2.13.1. Dokument urzędowy, [w:] Metodyka sporzadzania pism procesowych w sprawach karnych, cywilnych, gospodarczych $i$ administracyjnych, red. A. Cempura, A. Kasolik, Warszawa 2016, LEX. 
W orzecznictwie ugruntowany jest pogląd, iż świadectwo pracy nie jest dokumentem urzędowym w rozumieniu przepisów k.p.c. Także świadectwo wykonywania pracy w szczególnych warunkach nie jest dokumentem urzędowym w rozumieniu art. $244 \S 1$ i 2 k.p.c., ponieważ podmiot wydający to świadectwo nie jest organem państwowym ani organem wykonującym zadania z zakresu administracji państwowej. Świadectwa pracy będą traktowane w postępowaniu sądowym jako dokumenty prywatne w rozumieniu art. 245 k.p.c., stanowiące dowód tego, że osoba, która je podpisała, złożyła oświadczenie zawarte w przedmiotowych dokumentach. Będą one w związku z tym podlegać kontroli z urzędu oraz na zarzut co do faktów i prawidłowości wskazanej podstawy prawnej ${ }^{31}$. Co więcej, świadectwo pracy nie będzie miało charakteru dokumentu urzędowego nawet wówczas, gdy zostanie wydane przez o.a.p. Nie będzie to bowiem dokument sporządzony w zakresie działania administracji publicznej, ale w ramach stosunków cywilnoprawnych lub stosunków pracy ${ }^{32}$. Interesujące pozostaje, że w odniesieniu do służby w organach administracji publicznej, takich jak Państwowa Straż Pożarna czy organy Policji, nie wystawia się świadectwa pracy, ale świadectwo służby. Jest ono traktowane jako zaświadczenie w rozumieniu art. 217 k.p.a. ${ }^{33}$

Należy więc wskazać, jaki charakter można przypisać zaświadczeniom wydawanym przez podmioty prywatne. Wydaje się, że wszystkie, podobnie jak świadectwo pracy, będą dokumentami prywatnymi w rozumieniu art. 245 k.p.c.

\subsection{PODMIOTY UPRAWNIONE DO UZYSKANIA ZAŚWIADCZEŃ I PODMIOTY PRYWATNE ZOBOWIĄZANE DO ICH WYDANIA}

Podmiotem uprawnionym do uzyskania zaświadczenia od podmiotu prywatnego może być każdy, kto ma interes prawny lub faktyczny w uzyskaniu zaświadczenia bądź wymaga tego od niego przepis prawa. Wniosek o uzyskanie zaświadczenia nie musi zawierać szczegółowego uzasadnienia. Podmiot ubiegający się o wydanie zaświadczenia nie będzie miał przymiotu strony, w rozumieniu art. 28 k.p.a., nie będzie to również osoba uprawniona w rozumieniu art. 217 § 1 k.p.a.

Obowiązek wydania zaświadczenia w przypadku podmiotów prywatnych można wywodzić z przepisów prawa, przepisów wewnętrznych wiążących dane

31 Wyrok SA w Lublinie z dnia 9 lutego 2017 r., III AUa 910/16, LEX nr 2240084; wyrok SA w Łodzi z dnia 10 czerwca 2016 r., III AUa 1492/15, LEX nr 2071301; wyrok SA w Krakowie z dnia 31 maja 2016 r., III AUa 1189/15, LEX nr 2080866; wyrok SA w Lublinie z dnia 19 kwietnia 2016 r., III AUa 1191/15, LEX nr 2044262; wyrok SA w Rzeszowie z dnia 27 września 2012 r., III AUa 697/12, LEX nr 1223442.

32 Wyrok SN z dnia 20 lutego 1991 r., I PR 422/90, LEX nr 14682; wyrok SN z dnia 17 maja 1996 r., I PRN 40/96, LEX nr 25610; wyrok SN z dnia 14 maja 2012 r., II PK 238/11, LEX nr 1297781; wyrok SA w Gdańsku z dnia 22 marca 2016 r., III AUa 1752/15, LEX nr 2020077.

33 Postanowienie NSA z dnia 29 stycznia 1993 r., II SA 2468/92, LEX nr 10446; wyrok WSA w Szczecinie z dnia 27 września 2006 r., II SA/Sz 743/06, LEX nr 901914; wyrok NSA z 20 października 2010 r., I OSK 616/10, LEX nr 745274. 
podmioty albo z orzecznictwa. Zostało to wyartykułowane między innymi w wyroku SN z 16 czerwca 1999 roku $^{34}$, w którym podkreślono, że:

w ramach ogólnego obowiązku pracodawcy dbania o dobro pracownika mieści się powinność dostarczania pracownikowi informacji i dokumentów istotnych nie tylko z punktu widzenia realizacji stosunku pracy (świadectwa pracy, zaświadczenia o stażu pracy itp.), ale także zaświadczeń o zarobkach potrzebnych do realizacji uprawnień poza zakładem pracy ${ }^{35}$.

Podobnie jest w kwestii świadczeń emerytalnych i rentowych. Trafnie przyjęto, iż pracodawca, w myśl art. 125 ust. 1 pkt 2 ustawy z dnia 17 grudnia 1998 roku o emeryturach i rentach z Funduszu Ubezpieczeń Społecznych ${ }^{36}$, jest zobowiązany do współdziałania z pracownikiem i organem rentowym w gromadzeniu dokumentacji niezbędnej do przyznania świadczeń. Na pracodawcę nałożono tym samym obowiązek do wydania pracownikowi lub organowi rentowemu zaświadczeń niezbędnych do ustalenia prawa do świadczeń i ich wysokości. Odpowiedzialność pracodawcy będzie wynikała z przepisów prawa cywilnego. Warto podkreślić, iż z samego faktu, że pracodawca został zobligowany do współdziałania z pracownikiem przy ubieganiu się przez niego o świadczenia z ubezpieczenia społecznego, wynika wspomniany obowiązek wydania zaświadczeń niezbędnych do ustalenia prawa do świadczeń i ich wysokości ${ }^{37}$.

Analogiczne rozwiązanie zastosowano w art. 29 ust. 2 ustawy z dnia 28 listopada 2003 roku o świadczeniach rodzinnych ${ }^{38}$ (dalej: u.ś.r.). Zgodnie z treścią tego przepisu, pracodawcy i inne podmioty wymienione są obowiązani wydawać zaświadczenia niezbędne do ustalenia prawa do świadczeń rodzinnych. Wydawanie tych zaświadczeń jest wolne od opłat. O treści i elementach zaświadczenia decyduje, co do zasady, organ, który żąda przedłożenia zaświadczenia przez ubiegającego się o świadczenie rodzinne. Podmioty te mają opracowane własne wzory druków, które wnioskodawca oraz podmiot wystawiający zaświadczenie mają uzupełnić. Każde zaświadczenie będzie więc zróżnicowane pod względem zawartych w nim informacji, a wszelkie wątpliwości w tym zakresie powinien wyjaśniać organ, który żąda przedłożenia zaświadczenia. Jak wskazał WSA w Warszawie:

obowiązek sporządzenia wniosku zgodnie z wymogami ustawy oraz obowiązek zgromadzenia i załączenia dokumentów wymaganych przez ustawę spoczywa na osobie uprawnionej do jego złożenia. Natomiast w razie jakichkolwiek wątpliwości o.a.p. realizujący zadania w zakresie świadczeń rodzinnych jest zobowiązany do udzielenia wyczerpujących informacji osobie uprawnionej do złożenia wnioskü ${ }^{39}$.

34 Wyrok SN z dnia 16 września 1999 r., I PKN 331/99, OSNP 2001/9/314.

35 Ibidem.

36 Tekst jedn. Dz.U. z 2020 r. poz. 53 ze zm.

37 Uchwała SN z dnia 17 lutego 2005 r., II PZP 1/05, OSNP 2005/10/138.

38 Tekst jedn. Dz.U. z 2020 r. poz. 111 ze zm.

39 Wyrok WSA w Warszawie z dnia 30 sierpnia 2007 r., I SA/Wa 964/07, LEX nr 355309. 
Wskazuje się jednocześnie, że przepisy ustawy nie nakładają wprost na przywołane podmioty obowiązku wydawania zaświadczeń potrzebnych do uzyskania świadczenia rodzinnego ${ }^{40}$. Zwrócić należy jednocześnie uwagę na fakt, iż ustalenie prawa do świadczeń rodzinnych oraz ich wypłata następuje na wniosek podmiotów uprawnionych, wymienionych w art. 23 ust. 1 u.ś.r., które złożą wniosek wraz z wymaganymi dokumentami. Wśród dokumentów znaleźć musi się zaświadczenie od jednego z przywołanych podmiotów prywatnych. Ustalenie prawa do świadczeń rodzinnych oraz ich wypłata nie jest dopuszczalna bez wniosku zaopatrzonego w odpowiednie dokumenty. Tym samym niewydanie zaświadczenia przez podmiot prywatny mogłoby wiązać się z pozbawieniem osoby ubiegającej się o świadczenie rodzinne możliwości jego uzyskania. Sytuacja wydaje się wobec tego analogiczna do kazusu z wyroku SN z 1999 roku $^{41}$.

W związku z przytoczonymi przykładami obowiązek ciążący na podmiocie prywatnym wynikać może z podstawy materialnoprawnej, która jednocześnie obliguje osobę uprawnioną do uzyskania zaświadczenia, niezależnie od stanu faktycznego. Niewywiązanie się z tego obowiązku przez podmiot prywatny mający wydać zaświadczenie, może wiązać się z możliwością dochodzenia roszczeń osoby uprawnionej na drodze postępowania cywilnego.

Może się zdarzyć, że podmiot zobowiązany do wydania zaświadczenia, będzie pełnił funkcje podmiotu administracyjnego. Przykład stanowi rektor uczelni wyższej. Jeżeli pracownik uczelni zwróci się do rektora jako pracodawcy o wydanie zaświadczenia wymaganego przez bank w celu uzyskania kredytu, to wówczas rektor nie działa jako organ administracji publicznej, tylko jako podmiot zatrudniający. Zatem znaczenie będzie miała kwalifikacja podmiotu, gdyż o treści zaświadczenia decyduje podmiot, który żąda przedłożenia zaświadczenia (bank).

\section{TRYB WYDAWANIA ZAŚWIADCZEŃ PRZEZ ORGANY ADMINISTRACJI PUBLICZNEJ}

Czynności proceduralne stosowane przy wydawaniu zaświadczeń przez o.a.p. mają składać się na procedurę w swojej istocie odformalizowaną. Podmiotom ubiegającym się o wydanie zaświadczenia nie stawia się żadnych wymagań, a zgodnie z treścią art. $217 \S 1$ i 2 k.p.a. legitymację stanowi wyłącznie żądanie osoby ubiegającej się o wydanie zaświadczenia ${ }^{42}$. Należy pamiętać, iż odformalizowana procedura nie może wiązać się z brakiem rygorów proceduralnych, gdyż zaświadczenie wydane przez o.a.p. jest dokumentem urzędowym w rozumieniu

40 Wyrok Sądu Rejonowego dla Wrocławia-Śródmieścia we Wrocławiu z dnia 17 grudnia 2009 r., IV P 129/09; wyrok WSA we Wrocławiu z dnia 11 maja 2011 r., IV SA/Wr 28/11, LEX nr 995710.

41 Wyrok SN z dnia 16 września 1999 r., I PKN 331/99.

42 B. Adamiak, J. Borkowski, Postępowanie administracyjne..., s. 757. 
art. 76 k.p.a. W orzecznictwie podkreśla się, że przedmiot postępowania o wydanie zaświadczenia nie obejmuje kompetencji do orzekania przez organ w danej sprawie administracyjnej. Nie ma tutaj mowy o ustalaniu praw lub obowiązków administracyjnoprawnych podmiotów prawa. Istota wydania zaświadczenia sprowadza się wyłącznie do poświadczenia faktów lub stanów prawnych wynikających z dokumentów będących w dyspozycji organu, które wiążą się z zakresem wykonywanych przez niego ustawowych kompetencji. W tym świetle wydawanie zaświadczeń ma charakter pochodny ${ }^{43}$.

Postępowanie w sprawie wydania zaświadczenia może być wszczęte wyłącznie na wniosek osoby ubiegającej się o zaświadczenie. Osoba, która żąda wydania zaświadczenia, powinna złożyć wniosek odpowiadający wymaganiom z art. 63 k.p.a. lub ustnie do protokołu. Wszczęcie postępowania w sprawie wydania zaświadczenia następuje w dniu doręczenia żądania do organu administracji publicznej44 ${ }^{44}$ Ważne, by osoba żądająca wydania zaświadczenia nie zwróciła się do organu o jego wydanie w przedmiocie stwierdzenia istnienia faktów prawotwórczych. Ich ustalenie jest bowiem przedmiotem oceny prawnej organu w postępowaniu administracyjnym, kończącym się wydaniem decyzji administracyjnej. Organ nie będzie mógł wydać w takiej sprawie zaświadczenia, które potwierdza jedynie stan faktyczny lub prawny wynikający z danych posiadanych przez organ. Wydanie zaświadczenia jest jedynie czynnością materialno-techniczną ${ }^{45}$.

Organ jest zobowiązany wydać zaświadczenie bez zbędnej zwłoki, nie później jednak niż w terminie siedmiu dni od dnia otrzymania żądania. Jeśli dysponuje danymi, których zaświadczenie ma dotyczyć, powinien wydać je niezwłocznie.

O.a.p. może przeprowadzić postępowanie wyjaśniające, jeśli stan faktyczny lub prawny, który ma potwierdzić zaświadczenie, wymaga wyjaśnienia (art. 218 $\S 2$ k.p.a.). Organ nie może jednak czynić nowych ustaleń faktycznych ani pozyskiwać nowych dowodów. Zgodnie z orzecznictwem sądów administracyjnych nie jest dopuszczalne, by organ, w trybie procedury wydawania zaświadczeń, dokonywał jakichkolwiek ustaleń faktycznych i ocen prawnych niewynikających z prowadzonej przez niego ewidencji, rejestrów, kartotek bądź z innych danych znajdujących się w jego posiadaniu ${ }^{46}$.

Postępowanie w sprawie wydawania zaświadczeń kończy się wydaniem lub odmową wydania zaświadczenia osobie ubiegającej się o nie. Zaświadczenie wydaje się na piśmie lub w formie dokumentu elektronicznego z kwalifikowa-

43 Wyrok WSA w Łodzi z dnia 4 grudnia 2019 r., II SA/Ld 545/19, LEX nr 2756586; wyrok WSA w Warszawie z dnia 15 grudnia 2009 r., I SA/Wa 1616/09; wyrok WSA w Krakowie z dnia 21 maja 2014 r., III SA/Kr 91/14, LEX nr 1531853.

${ }^{44}$ L. Klat-Wertelecka, Zaświadczenie w prawie administracyjnym, Warszawa 2001, s. 72.

45 Wyrok SA w Poznaniu z dnia 20 stycznia 2016 r., III AUa 775/15, LEX nr 2025591.

46 Wyrok WSA w Łodzi z dnia 4 grudnia 2019 r., II SA/Łd 545/19; wyrok WSA w Warszawie z dnia 15 grudnia 2009 r., I SA/Wa 1616/09; wyrok WSA w Krakowie z dnia 21 maja 2014 r., III SA/Kr 91/14. 
nym podpisem elektronicznym, jeśli żąda tego osoba ubiegająca się o wydanie zaświadczenia. Odmowa wydania zaświadczenia bądź zaświadczenia o treści żądanej przez osobę ubiegającą się o nie, następuje w drodze postanowienia, na które służy zażalenie (art. 219 k.p.a.). Choć z treści art. 218 § 1 k.p.a. wynika, że organ jest obowiązany do wydania zaświadczenia, gdy chodzi o potwierdzenie faktów albo stanu prawnego, wynikających z prowadzonej przez ten organ ewidencji, rejestrów bądź z innych danych znajdujących się w jego posiadaniu, to może on odmówić ze względu na ochronę danych osobowych lub sprzeczność żądania z posiadanymi danymi ${ }^{47}$. Odmowa może zatem nastąpić, gdy nie można wydać zaświadczenia osobie, która się o nie ubiega, bądź nie można wydać zaświadczenia o określonej treści. W tych dwóch sytuacjach przysługuje zażalenie na wydane przez organ postanowienie. Zażalenie nie przysługuje na zaświadczenie wydane przez organ, jeżeli strona nie zgadza się z jego treścią. W takiej sytuacji powinna złożyć ponowny wniosek o wydanie zaświadczenia o określonej treści i dopiero w przypadku wydania przez organ postanowienia o odmowie wydania zaświadczenia takiej treści, będzie jej przysługiwał środek zaskarżenia w postaci zażalenia $^{48}$.

Choć przepisy działu VII k.p.a. nie odsyłają do odpowiedniego stosowania przepisów o postanowieniach wskazuje się, że należy się nimi posłużyć w odniesieniu do postanowienia o odmowie wydania zaświadczenia ${ }^{49}$. Postanowienie to musi czynić zadość wszystkim wymaganiom z art. 124-125 k.p.a. Zażalenie na postanowienie należy wnieść w terminie siedmiu dni od dnia jego otrzymania, do organu wyższego stopnia, za pośrednictwem organu, który wydał zaskarżane postanowienie. W wyniku rozpatrzenia sprawy przez organ wyższego stopnia, postanowienie zostanie utrzymane w mocy lub uchylone, a organ pierwszej instancji będzie zobowiązany do wydania żądanego zaświadczenia.

\section{TRYB WYDAWANIA ZAŚWIADCZEŃ PRZEZ PODMIOTY PRYWATNE}

Akty potwierdzające stan faktyczny lub stan prawny wydane przez podmioty inne niż o.a.p. w rozumieniu art. $5 \S 2$ pkt 3 k.p.a. nie są zaświadczeniami w rozumieniu k.p.a.

Regulacja kodeksowa nie dotyczy zatem innych zaświadczeń, w szczególności wydawanych przez osoby fizyczne oraz organy niebędące organami w znaczeniu wyżej wyjaśnionym [...]. Poza zasięgiem działania kodeksu pozostają także zaświadczenia pochodzące wprawdzie od o.a.p., ale

47 B. Adamiak, J. Borkowski, Postępowanie administracyjne..., s. 761.

48 Wyrok WSA w Łodzi z dnia 17 stycznia 2013 r., III SA/Ld 982/12, LEX nr 1270580; wyrok WSA we Wrocławiu z dnia 20 lutego 2013 r., II SA/Wr 766/12, LEX nr 1330024; wyrok WSA we Wrocławiu z dnia 19 maja 2016 r., II SA/Wr 140/16, LEX nr 2085431.

49 B. Adamiak, J. Borkowski, Postępowanie administracyjne..., s. 762. 
wydawane z urzędu, a także takie, których treść wykracza poza stwierdzenie obiektywnie istniejącego (aktualnie bądź w przeszłości) stanu rzeczy ${ }^{50}$.

Osoby, które ubiegają się o wydanie zaświadczenia przez podmioty prywatne, mogą występować o ich wydanie z różnych powodów — ponieważ wymaga tego przepis prawa, z uwagi na swój interes prawny, a nawet interes faktyczny. Sytuacje, w których żądanie wydania zaświadczenia składa się do innych podmiotów niż o.a.p., nie są rzadkie. Za przykłady mogą posłużyć art. 121a ustawy z dnia 14 grudnia 2016 roku — Prawo oświatowe ${ }^{51}$, wspomniany wcześniej art. 29 ust. 2 u.ś.r., konieczność uzyskania zaświadczenia o zarobkach przy ubieganiu się o wszelkiego rodzaju kredyty, czy też w przypadku ubiegania się o emeryturę czy rentę.

Stronami postępowania w sprawie wydania zaświadczenia będącego dokumentem prywatnym są podmiot, który ubiega się o wydanie zaświadczenia, oraz podmiot prywatny, który takie zaświadczenie wydaje. Podmiot prywatny jest zobowiązany do wydania stosownego zaświadczenia, tylko gdy przepis prawa nakłada na niego taki obowiązek ${ }^{52}$. W przeciwnym razie wydanie żądanego zaświadczenia uzależnione jest od woli podmiotu, który miałby je wydać.

Katalog osób uprawnionych do ubiegania się o zaświadczenie jest bardzo szeroki. Mieszczą się w nim osoby fizyczne, osoby prawne, a także jednostki organizacyjne nieposiadające osobowości prawnej.

Wspólne w postępowaniu w sprawie wydawania zaświadczeń regulowanym przez przepisy k.p.a. i postępowaniu, które toczy się przed podmiotami prywatnymi, jest wszczynanie ich na żądanie osoby ubiegającej się o ten dokument. Postępowanie takie nie zostanie wszczęte $z$ urzędu ${ }^{53}$. Nie ma przepisów, które regulowałyby kwestię formy zgłaszania tegoż żądania. Można zatem przyjąć, iż jest ona dowolna, byleby tylko żądanie określonej treści dotarło do podmiotu prywatnego, który ma wydać zaświadczenie. Żądanie może zostać zgłoszone ustnie, pisemnie, a także za pomocą środków komunikacji elektronicznej. Wniosek powinien zawierać: dane identyfikujące osobę występującą z żądaniem — jej imię, nazwisko, nazwę, adres, wskazanie okoliczności, dla których zainteresowany zwraca się $\mathrm{z}$ wnioskiem o wydanie zaświadczenia, na przykład wskazanie przepisu prawa, który wymaga potwierdzenia określonych faktów lub stanu prawnego, wskazanie interesu prawnego, wskazanie interesu faktycznego, a także podpis osoby ubiegającej się o zaświadczenie. Dniem wszczęcia przedmiotowego postępowania będzie dzień, w którym podmiot prywatny zapozna się z treścią wniosku.

50 Z.R. Kmiecik, Instytucja zaświadczenia..., s. 22.

51 Tekst jedn. Dz.U. z 2020 r. poz. 910. Podmiot przyjmujący na staż uczniowski jest obowiązany wystawić na piśmie zaświadczenie o odbyciu stażu uczniowskiego, które określa w szczególności okres odbytego stażu uczniowskiego, rodzaj realizowanych zadań i umiejętności nabyte w czasie odbywania stażu uczniowskiego.

52 Przykład stanowi art. 29 ust. 2 u.ś.r.

53 Z.R. Kmiecik, Instytucja zaświadczenia..., s. 77. 
Przepisy nie regulują kwestii związanej z terminem wydania zaświadczenia przez podmiot prywatny. Uznać należy, że podmiot prywatny powinien wydać je, zanim zakończy się postępowanie, w ramach którego wymaga się od pomiotu występującego o zaświadczenie, dokumentu o żądanej treści. Treść zaświadczenia będzie podyktowana przez podmiot, który wymaga jego przedłożenia przez osobę ubiegającą się o jego wydanie.

Przepisy prawa nie dają także odpowiedzi na pytanie, czy podmioty prywatne, do których zwrócono się o wydanie zaświadczenia, muszą lub mogą badać, czy powody kierujące osobą ubiegającą się o zaświadczenie faktycznie istnieją.

Jak wcześniej wskazano, nie zawsze podmiot prywatny będzie zobowiązany do wydania zaświadczenia. Czy istnieją mechanizmy, za pomocą których osoba ubiegająca się o wydanie przedmiotowego dokumentu może wyegzekwować wydanie zaświadczenia przez podmiot, do którego się zwróciła? W postanowieniu z dnia 16 września 1999 roku SN wskazał, iż powinnością pracodawcy jest dbałość o dobro pracownika oparta na zasadach współżycia społecznego ${ }^{54}$. Odmowa wydania zaświadczenia o zarobkach w sytuacji ubiegania się o kredyt nie realizuje zasady dbałości o jego dobro, stanowi wykroczenie przeciwko prawom pracownika. W myśl art. 300 ustawy z dnia 26 czerwca 1974 roku — Kodeks pra$\mathrm{cy}^{55} \mathrm{w}$ sprawach nieunormowanych przepisami prawa pracy, do stosunku pracy stosuje się odpowiednio przepisy kodeksu cywilnego, jeżeli nie są one sprzeczne $\mathrm{z}$ zasadami prawa pracy, a zatem możliwe jest $\mathrm{w}$ takim przypadku stosowanie art. 415 k.c.

W większości przypadków odmowa pracodawcy dotycząca wydania zaświadczenia o zatrudnieniu i zarobkach może być potraktowana jako działanie na szkodę zainteresowanego (pracownika). Mowa o takich sytuacjach, gdy na skutek braku aktualnego zaświadczenia zatrudniony nie otrzymał kredytu. [...] W takich sytuacjach k.c. przewiduje, że ten, „kto z winy swojej wyrządził drugiemu szkodę, obowiązany jest do jej naprawienia”. Czasami naprawa szkody nie jest możliwa lub nie wystarcza do całkowitego zaspokojenia roszczeń poszkodowanego. Wówczas można pokusić się o złożenie powództwa dotyczącego wypłaty odszkodowania [...], a także zadośćuczynienie ${ }^{56}$.

Ponadto w uchwale z dnia 17 lutego 2005 roku SN orzekł, że pracodawca jest obowiązany do wydania pracownikowi zaświadczeń niezbędnych do ustalenia prawa do świadczeń emerytalnych lub rentowych. W myśl art. 180 § 1 k.p.a. w sprawach z zakresu ubezpieczeń społecznych stosuje się przepisy kodeksu, chyba że przepisy dotyczące ubezpieczeń ustalają odmienne zasady postępowania w tych sprawach. Takiego charakteru nie ma sprawa, której przedmiotem jest zobowiązanie pracodawcy do wydania określonego zaświadczenia — w tym wypadku

54 Postanowienie SN z dnia 16 września 1999 r., I PKN 331/99.

55 Tekst jedn. Dz.U. z 2020 r. poz. 1320.

${ }^{56}$ H. Gronek, Czy pracodawca może odmówić wystawienia zaświadczenia o zarobkach?, https://www.zadluzenia.com/czy-pracodawca-moze-odmowic-wystawienia-zaswiadczenia-o-zar obkach/?fbclid=IwAR1oPeciJQ8MzGPXeNmx-lzi9qt9c-gzF9ku9PTFQS1NROFE1ui6BrureMk (dostęp: 16.12.2020). 
zaświadczenia o zatrudnieniu i wynagrodzeniu uzyskiwanym w toku zatrudnienia. Pracodawca jest zobowiązany do wydania pracownikowi zaświadczenia, a więc gdy odmawia sporządzenia takiego dokumentu, popełnia wykroczenie przeciwko prawom pracownika. Może to nadto uzasadniać jego odpowiedzialność odszkodowawczą. Istnieje więc materialnoprawna podstawa do wytoczenia przez pracownika powództwa o zobowiązanie pracodawcy do wydania stosownego dokumentu ${ }^{57}$. W razie odmowy wydania zaświadczenia przez pracodawcę, SN dopuścił możliwość wejścia na drogę sądową w postępowaniu cywilnym. Gdy pracodawca uchybia temu obowiązkowi, pracownikowi służy roszczenie o wydanie takiego dokumentu, a sprawa taka jako związana ze stosunkiem pracy — proceduralnie byłaby sprawą cywilną (art. 1 k.p.c.). Osoby ubiegające się o wydanie zaświadczenia przez podmioty prywatne mogą więc skutecznie dochodzić swoich roszczeń.

\section{PODSUMOWANIE}

Nieuregulowanie kwestii wydawania zaświadczeń przez podmioty prywatne prowadzi do konieczności oparcia argumentacji i poglądów w tym zakresie na dorobku doktryny oraz orzecznictwa sądów administracyjnych i powszechnych. $\mathrm{Z}$ dokonanej przez autorki analizy wyprowadzić można wniosek, że zaświadczenia wydane przez podmioty prywatne mają charakter dokumentów prywatnych w rozumieniu przepisów k.p.c. Nie korzystają tym samym z domniemań prawnych, jakimi objęte są dokumenty o charakterze urzędowym, w rozumieniu przepisów zarówno k.p.a., jak i k.p.c. Do procedury wydawania zaświadczeń przez podmioty prywatne nie będą miały zastosowania przepisy działu VII k.p.a.

Jednocześnie zauważyć należy, w kontekście wskazanego orzecznictwa, że choć podmioty prywatne nie są związane przepisami w zakresie swoich czynności, to obowiązek wydania przez nie zaświadczenia na żądanie osoby uprawnionej może wynikać z przepisów prawa materialnego. Ten, jak zostało zauważone, jednocześnie nakłada obowiązek uzyskania owego zaświadczenia przez osobę uprawnioną. Nieuzyskanie zaświadczenia pociąga za sobą niemożność ubiegania się o określone świadczenia lub uzyskania innych korzyści wynikających z interesu prawnego, faktycznego lub bezpośrednio z przepisów prawa. Tym samym osoba, która żąda wydania zaświadczenia, może dochodzić swoich roszczeń od podmiotu prywatnego, który odmówił wydania zaświadczenia, na drodze cywilnej. Wydanie zaświadczenia w tym wypadku wynika bowiem ze stosunków cywilnoprawnych lub stosunku pracy ${ }^{58}$.

57 Uchwała SN z dnia 17 lutego 2005 r., II PZP 1/05, OSNP 2005/10/138.

58 Nie ma to jednak zastosowania w przypadku stosunku służby, na co wskazano w pkt 3.1 niniejszego opracowania. 
Podsumowując, można z pewnością wskazać, iż osoby ubiegające się o wydanie zaświadczenia przez podmioty prywatne nie są pozbawione ochrony prawnej mimo braku regulacji w tym zakresie. Obowiązek ciążący na podmiotach prywatnych powinien zostać zrealizowany, zwłaszcza jeśli wydanie zaświadczenia jest niezbędne $\mathrm{z}$ formalnego punktu widzenia do uzyskania przez osobę uprawnioną określonego przepisami świadczenia.

\title{
LEGAL NATURE OF CERTIFICATES ISSUED BY PRIVATE BODIES AND THE PROCEDURE FOR ISSUING THEM
}

\author{
Summary
}

The study analyses the views of doctrine and jurisprudence of administrative and common courts in order to resolve the issue of passing certificates by private entities. The authors have attempted to classify the private certificates and the mode of its issuance. The aim of the study was to indicate the obligation of private entities to pass the certificate at the request of the entitled person and the issue of legally protecting that person.

Keywords: certificate, private entity, mode of private certificates issuance, mode of passing certificates

\section{BIBLIOGRAFIA}

Adamiak B., Borkowski J., Kodeks postępowania administracyjnego. Komentarz, Warszawa 2017. Adamiak B., Borkowski J., Kodeks postępowania administracyjnego. Komentarz, Warszawa 2021, Legalis.

Adamiak B., Borkowski J., Postępowanie administracyjne i sq̨dowoadministracyjne, Warszawa 2018. Borkowski J., Jendrośka J., Orzechowski R., Zieliński A., Kodeks postępowania administracyjnego. Komentarz, Warszawa 1989.

Cempura A., Kasolik A., Metodyka sporządzania pism procesowych w sprawach karnych, cywilnych, gospodarczych i administracyjnych, Warszawa 2016, LEX.

Gronek H., Czy pracodawca może odmówić wystawienia zaświadczenia o zarobkach?, https://www. zadluzenia.com/czy-pracodawca-moze-odmowic-wystawienia-zaswiadczenia-o-zarobkach/ ?fbclid=IwAR1oPeciJQ8MzGPXeNmx-lzi9qt9c-gzF9ku9PTFQS1NROFE1ui6BrureMk.

Janowicz Z., Postepowanie administracyjne i postepowanie przed sqdem administracyjnym, Warszawa-Poznań 1987.

Klat-Wertelecka L., Zaświadczenie w prawie administracyjnym, Warszawa 2001.

Kmiecik Z.R., Instytucja zaświadczenia w prawie administracyjnym, Lublin 2002.

Kmiecik Z.R., Charakter prawny zaświadczenia a możliwość ustalania i weryfikacji jego treści, „Państwo i Prawo” 2004, nr 10, s. 47-57.

Kodeks postepowania administracyjnego. Komentarz, red. H. Knysiak-Sudyka, Warszawa 2019, LEX.

Lang J., Poglądy nauki na funkcje i charakter zaświadczeń, „Organizacja, Metody, Technika” 1988, $\mathrm{nr} 1$.

Lang J., Zaświadczenia w rozumieniu kodeksu postępowania administracyjnego, „Organizacja, Metody, Technika" 1988, $\mathrm{nr} 2$.

Wilbrandt-Gotowicz M., Wróbel A., Jaśkowska M., Kodeks postępowania administracyjnego. Komentarz aktualizowany, Gdańsk 2020, LEX. 